Article

\title{
The Transformation of Coal-Mining Waste Minerals in the Pozzolanic Reactions of Cements
}

\author{
Rosario García-Giménez ${ }^{1, *}$, Raquel Vigil de la Villa Mencía ${ }^{1}$, Virginia Rubio ${ }^{2}$ and \\ Moisés Frías ${ }^{3}$ \\ 1 Dpto de Geología y Geoquímica, Unidad Asociada CSIC-UAM, Universidad Autónoma de Madrid, \\ 28049 Madrid, Spain; raquel.vigil@uam.es \\ 2 Dpto de Geografía, Unidad Asociada CSIC-UAM, Universidad Autónoma de Madrid, 28049 Madrid, Spain; \\ virginia.rubio@uam.es \\ 3 Eduardo Torroja Institute (CSIC), Spanish National Research Council, 28033 Madrid, Spain; \\ mfrias@ietcc.csic.es \\ * Correspondence: rosario.garcia@uam.es; Tel.: +34-914-974-819
}

Academic Editors: Shifeng Dai, Xibo Wang and Lei Zhao

Received: 22 January 2016; Accepted: 22 June 2016; Published: 30 June 2016

\begin{abstract}
The cement industry has the potential to become a major consumer of recycled waste materials that are transformed and recycled in various forms as aggregates and pozzolanic materials. These recycled waste materials would otherwise have been dumped in landfill sites, leaving hazardous elements to break down and contaminate the environment. There are several approaches for the reuse of these waste products, especially in relation to clay minerals that can induce pozzolanic reactions of special interest in the cement industry. In the present paper, scientific aspects are discussed in relation to several inert coal-mining wastes and their recycling as alternative sources of future eco-efficient pozzolans, based on activated phyllosilicates. The presence of kaolinite in this waste indicates that thermal treatment at $600{ }^{\circ} \mathrm{C}$ for $2 \mathrm{~h}$ transformed these minerals into a highly reactive metakaolinite over the first seven days of the pozzolanic reaction. Moreover, high contents of metakaolinite, together with silica and alumina sheet structures, assisted the appearance of layered double hydroxides through metastable phases, forming stratlingite throughout the main phase of the pozzolanic reaction after 28 days (as recommended by the European Standard) as the reaction proceeded.
\end{abstract}

Keywords: metakaolinite; micas; coal-mining waste; LDH (layered double hydroxides); pozzolanic reaction

\section{Introduction}

A key vector of opportunity in the construction sector, in general, and for manufacturers of cement-based materials, in particular, is the efficient use of materials and energy resources, which moderates the carbon footprint of the final products. Our production of cements, mortars, and concretes, the most widely manufactured materials on the planet, involves energy-intensive exploitation of raw materials that remains a source of extremely high $\mathrm{CO}_{2}$ emissions.

The research, validation, and enhancement of new mineral additives for cement should ensure their availability in sufficient quantities for profitable investments, thereby reducing the environmental impacts of Portland-cement-clinker production, the overall volume of waste products, and the energy consumption of the final product. These additives also assist reactivity that densifies the hydration products.

The coal industry, more than any other sector, has one of the most negative effects on the environment. Coal waste (in abundant amounts from various extraction processes) is disposed 
of in landfills or is incinerated [1]. The use of coal waste to prevent environmental impacts has been explored in China [2] and elsewhere [3], especially in relation to building [4].

Coal-mining waste from the extraction and washing of debris from mines contains kaolinite, illite, and quartz of varying composition according to geological conditions and methods of extraction and purification. Above all, the composition of claystones generally consists of illite and kaolinite. Ferrous minerals, quartz, and carbonic matter may also be found in small amounts. All carboniferous rocks may also contain dolomitic veins, pyritic encrustations, and extensive quantities of plant detritus [4].

Pozzolans found in industrial waste have been linked to environmental and technological advantages that have driven research into their use. The incorporation of these industrial by-products and wastes together with natural materials in various production stages of blended cements was first prioritized in the cement industry. Experimentation with rice husk, fly ash, and palm oil has all been reported in the literature [5-8]. Materials with "pozzolanic" properties are linked to siliceous/aluminous materials. When added to water as fines, they can form cementitious properties in reaction with $\mathrm{Ca}(\mathrm{OH})_{2}$ [9]. Another class of pozzolans is from natural raw sources (volcanic material, limestone) or calcined materials (burnt shale, calcined kaolinite) with pozzolanic properties $[10,11]$. Blended with lime, their use in construction projects has been documented throughout history; natural pozzolans from magma deposits following volcanic activity have been added to mortars since classical antiquity. Natural pozzolans continue to be applied in many cement manufacturing processes to this day.

Calcined clays with pozzolanic activity draw structural water from the layers of crystalline clay, leaving amorphous or semi-amorphous materials with high surface areas and chemical reactivity.

Thermal activation of kaolinite at controlled temperatures produces metakaolinite, a product with highly pozzolanic properties. The investigation of thermal activation, within the ranges of between 650 and $750{ }^{\circ} \mathrm{C}$ with kaolinite-containing waste, resulted in products with a high latent pozzolanicity [12-18].

The works of Li et al. [19] and Beltramini et al. [20] pioneered the study of cement matrices containing activated coal-mining waste, providing useful results for future research. However, performance criteria at the percentages of coal-mining waste that they added and its activation conditions still require further research. Currently, studies in this investigative field are multiplying [21-23].

In this paper, the mineralogical transformations of coal waste are studied across a range of temperatures $\left(500-900{ }^{\circ} \mathrm{C}\right)$ for the establishment of optimum calcination conditions that yield products with sufficient pozzolanic properties to be used as additives in the manufacture of cements and related materials.

\section{Materials and Methods}

\subsection{Materials}

Mining generates high volumes of waste that are currently dumped in slag heaps of no apparent utility. Our study concerns coal-mining waste supplied by a coal-mining company (Sociedad Anónima Hullera Vasco-Leonesa) in Santa Lucía (Province of León, Spain). The mine supplies coal to the power plant in the region of La Robla, and the mine waste employed in this study is used in a cement factory in the same region.

The geological materials from La Robla vary greatly. They are separated by easily identifiable irregularities and contain a variety of rocks: metamorphic shales and sedimentary limestone and dolomite with Facies Utrillas (detrital deposit formed in a sedimentary environment of river systems). Igneous activity is very low and only found in small porphyry dikes [24].

The waste products from that area are reasonably uniform and contain white quartzite with highly recrystallized micro-conglomerates, feldspar mixed with sandstone, foliated slate (containing 
phyllite with mica and quartz, sericite, chlorite, zircon, pyrite, monazite, apatite, and tourmaline). The structure of dolomite changes in contact with St Lucia limestones and develops reddish hues.

There are grey limestones, found in marine environments, interbedded in massive reefs, with fauna in the form of bryozoans, crinoids, and brachiopods.

The mining waste material under study (coal, ore, and gangue with charcoal remains) was heat treated at different temperatures for activation, converting the kaolinite into metakaoline, among others chemical reactions.

Following its thermal activation at temperatures of 500,600, 700, 800 and $900{ }^{\circ} \mathrm{C}$ for $2 \mathrm{~h}$ in an electric laboratory furnace, the best activation conditions were selected for use as a pozzolan in the manufacture of cement. The activated samples were placed in an agate mortar and pestle and crushed to particle sizes of less than $63 \mu \mathrm{m}$.

\subsection{Methods}

Chemical characterization was performed with a Philips PW 1404 X-ray Fluorescence (XRF) Spectrometer (Philips, Eindhoven, The Netherlands), Loss on ignition (LOI) was calculated in accordance with the method specified in the European standard (at $950{ }^{\circ} \mathrm{C} / 1 \mathrm{~h}$ ). Bulk sample mineralogical compositions were analyzed by random powder X-ray diffraction (XRD), using the oriented film method for the $<2 \mu \mathrm{m}$ fraction, employing a $\mathrm{Cu}$ anode and a Siemens D-5000, X-ray diffractometer (Siemens, Madrid, Spain) in both instances. The operating conditions were, respectively, $30 \mathrm{~mA}$ and $40 \mathrm{kV}$, with a divergence slit of $2 \mathrm{~mm}$ and a receiving slit of $0.6 \mathrm{~mm}$. Each sample was scanned $(2 \theta)$ at steps of 0.041 and a count time of 3-s. Bulk sample characterization and semi-quantification used the random-powder method, between $3^{\circ}$ to $65^{\circ} 2 \theta$ at a rate of $2^{\circ} / \mathrm{min}$. Determination of phyllosilicates in the $<2 \mu \mathrm{m}$ fraction employed the oriented-slides method, operating from $2^{\circ}$ to $40^{\circ}$ at a scan rate of $1^{\circ} / \mathrm{min}$. The Rietveld method was used for quantitative determination of the mineralogical composition.

A Thermo Scientific NICOLET 6700 spectrometer fitted with a DGTS CsI detector (Thermo Fisher, Waltham, MA, USA) performed the FTIR (Fourier Transform Infrared Spectroscopy) analyses, recording 64 scans on the samples. Specimen preparation was done by mixing $1 \mathrm{mg}$ of the sample in $300 \mathrm{mg}$ of $\mathrm{KBr}$. Spectral analyses within the range of $4000-400 \mathrm{~cm}^{-1}$ was performed at a spectral resolution of $4 \mathrm{~cm}^{-1}$.

A Renishaw Raman RM2000 Microscope System (Renishaw, Wotton-under-Edge, UK) fitted with a Leica microscope (Leica, Wetzlar, Germany), an electrically refrigerated charge-coupled device camera (CCD), a $785 \mathrm{~nm}$ diode laser, and a $633 \mathrm{~nm}$ He-Ne Renishaw RL633 laser (Renishaw) were used to record dispersive Raman spectra at $633 \mathrm{~nm}$. Frequency calibration used a $520 \mathrm{~cm}^{-1}$ silicon line with a spectral resolution at $4 \mathrm{~cm}^{-1}$. A $50 \times$ lens was used for triplicate spectra recordings over wave ranges of $4000-100 \mathrm{~cm}^{-1}$ at $10 \mathrm{~s}$ exposure times with 10 accumulations for each spectrum.

An Inspect FEI Company Electron Microscopy (Hillsboro, OR, USA) fitted with an energy dispersive X-ray analyzer (W source, DX4i analyzer and Si/Li detector) performed SEM/EDX (Scanning Electron Microscopy/Energy Dispersive X-Ray Spectroscopy) a morphological observation and microanalysis for each sample. The average chemical composition of each sample was based on ten analyses.

An accelerated chemical method was applied to solid waste in order to study the pozzolanic behavior of a pozzolan/calcium hydroxide (lime) system. The test involves leaving the material ( $1 \mathrm{~g})$ in a lime-saturated solution $(75 \mathrm{~mL})$ and analyzing the $\mathrm{CaO}$ concentrations at 1,7 , and 28 days into the reaction time. The difference between its concentration in the lime-saturated control solution $(17.69 \mathrm{mmol} / \mathrm{L})$ and the Cao content of the solution in contact with the sample gave the combined $\mathrm{CaO}(\mathrm{mmol} / \mathrm{L})$ content. The hydrated solid sample was then filtered, washed in ethanol, and heated at $60{ }^{\circ} \mathrm{C}$ for $24 \mathrm{~h}$ until the hydration reaction ended [25]. 


\section{Discussion and Results}

\subsection{Raw-Carbon Wastes}

The XRF results in relation to the carbon waste (initial sample without treatment) showed that the main oxides were $\mathrm{SiO}_{2}(57 \%), \mathrm{Al}_{2} \mathrm{O}_{3}(25 \%), \mathrm{Fe}_{2} \mathrm{O}_{3}(5 \%), \mathrm{CaO}(4 \%)$, and $\mathrm{K}_{2} \mathrm{O}(3 \%)$, with some $\mathrm{SO}_{3}$ $(0.29 \%)$ as well. Loss on ignition (LOI) was $15 \%$ for initial waste and $3 \%$ for material that had been calcined at $500{ }^{\circ} \mathrm{C}$; this change is related to the dehydroxylation processes of kaolinite and organic matter (carbon). Minor elements or traces were also present, such as chromium (120 ppm), vanadium (139 ppm), nickel (53 ppm), and cobalt (21 ppm).

XRD analysis showed the mineralogical composition of the carbon waste (room temperature), revealing the existence of mica (25\%) and kaolinite (14\%), quartz (37\%), calcite (17\%), dolomite (5\%), and feldspars (2\%) (Figures 1 and 2). Both mica and kaolinite contribute to pozzolanic activity, as it is well established that atmospheric thermical activation of a variety of clay minerals at $600{ }^{\circ} \mathrm{C} / 900{ }^{\circ} \mathrm{C}$ following dehydroxylation causes the (partial) destruction of the crystal lattice structure, leading to a transitional and highly reactive phase. Mica requires temperatures over $930{ }^{\circ} \mathrm{C}$ for its activation and, as a result, it usually results in a weak pozzolan; tending to dissipate at temperatures over $900{ }^{\circ} \mathrm{C}$.

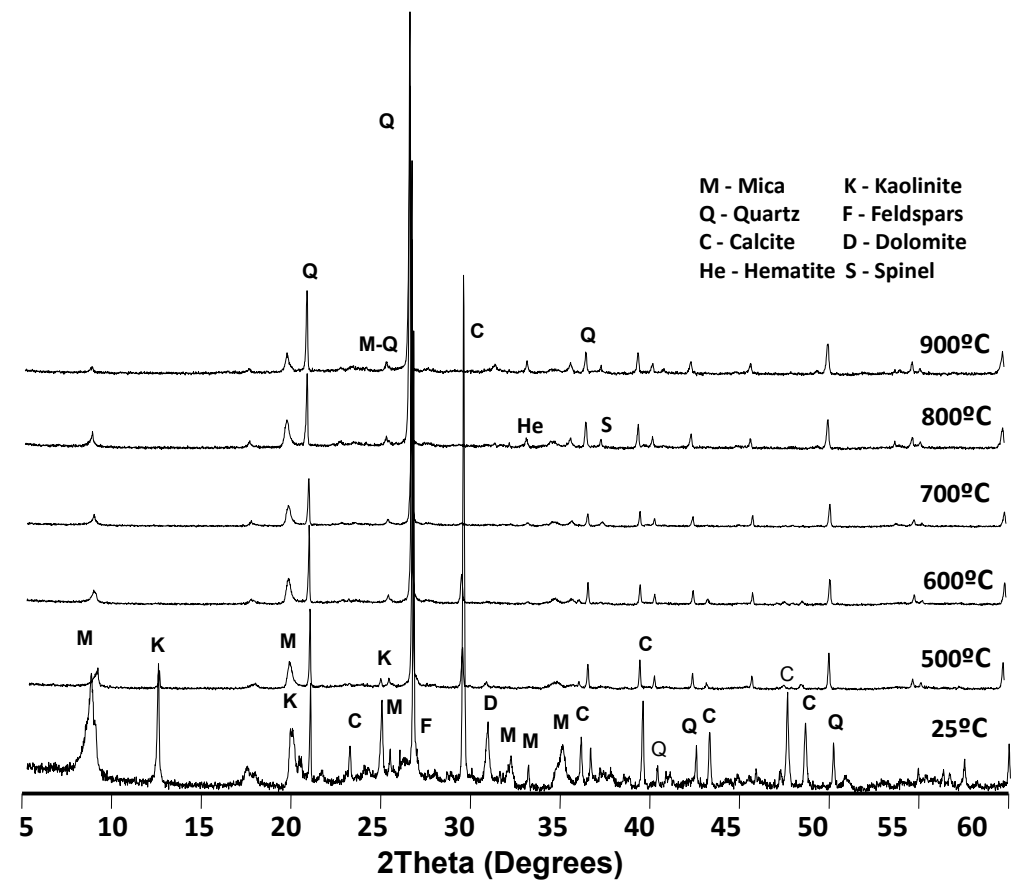

Figure 1. Mineralogical composition by X-ray diffraction (XRD) for the coal mining waste and the coal mining activated waste.

The XRD analysis also showed the formation of anorthite, the presence of which might be due to metakaolinite (from clay dehydration) reacting with calcium carbonate. The formation of mullite that the clay would otherwise generate during firing can be reduced by metakaolinite in reaction with calcium carbonate [26].

In comparison to the samples of coal-mining waste used in this study, in general terms, coal contains aluminum-bearing minerals that include kaolinite, illite, montmorillonite, chlorite, sanidine, albite, plagioclase, biotite, hornblende, and muscovite [27-30]. South African coal samples, for instance, contain quartz, kaolinite, illite I/S, calcite, dolomite, siderite, pyrite, analcite, basanite, bohemite, anatase, diaspore, and jarosite [31].

Even though it was not identified in the unheated sample in this study, the prevalent clay mineral in most South African coals is kaolinite [32-34] and would therefore be found in the raw coal. However, 
anhydrite and hematite, identified in the ash produced at $350{ }^{\circ} \mathrm{C}$, have not been observed in South African coals. Their presence in the heated samples used in the present study might suggest an alternative origin.

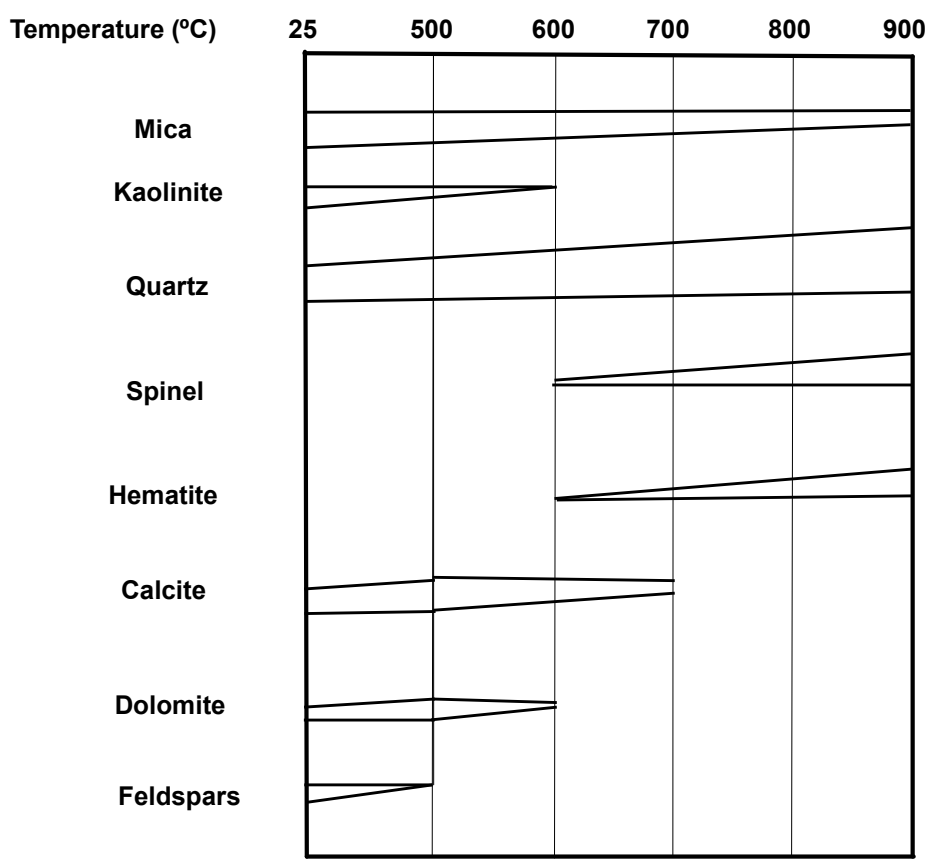

Figure 2. Mineralogical evolution by XRD for the coal mining waste and the coal mining activated waste.

In contrast, the main compounds reported in Australian coals are quartz, kaolinite, illite/smectite, calcite, dolomite, albite, siderite, pyrite, albite, apatite, gypsum, hematite, and anatase [35].

Calcite is the main carbonate mineral in Taoshuping coals with an average content of $9 \%$, and lower amounts of siderite, anchorite, and dolomite [36].

\subsection{Activated Coal-Mining Waste}

After analyzing the samples of coal waste, they were then thermically activated by calcination at between 500 and $900^{\circ} \mathrm{C}$. In Figures 1 and 2, the XRD patterns of the activated products at different temperatures are shown. The spectra reflects low levels of quartz and kaolinite dissipated at $600{ }^{\circ} \mathrm{C} / 2 \mathrm{~h}$ of thermical activation, due to their transformation into metakaolinite. Detrital quartz can also be cell-, cleat-, and fracture-fillings that are epigenetic in nature or syngenetic, such as aluminosilicates in coal $[33,34,37]$.

The temperature at which kaolinite is calcinated to produce metakaolinite in the active state lies within the range of $600-800^{\circ} \mathrm{C}$. The activation of mica requires temperatures over $930^{\circ} \mathrm{C}$, although it usually produces poor pozzolans. Temperature tests (at 500, 600, 700, 800 and $900{ }^{\circ} \mathrm{C}$ ) determined both phyllosilicate dehydroxylation and new phase-formation temperatures. Further studies were conducted after this test at 600 and at $900{ }^{\circ} \mathrm{C}$, showing that $600{ }^{\circ} \mathrm{C}$ was the total dehydroxylation temperature of kaolinite and its neoformation into spinel-like phases took place at $900{ }^{\circ} \mathrm{C}$.

Quasi-stable dehydroxylated mica was formed following dehydroxylation after thermical treatment between 700 and $900{ }^{\circ} \mathrm{C}$. The quasi-stable dehydroxylated phases of these dioctahedral micas were unlike the trioctahedral mica phases, which tended to dehydroxylate and recrystallize more or less simultaneously. Dehydroxylation of the 2:1 mica layers needed higher temperatures. At $600^{\circ} \mathrm{C} / 2 \mathrm{~h}$, a new characteristic peak appeared, explained by the appearance of hematite. As the heating increased from 700 to $900^{\circ} \mathrm{C}$, both hydrous oxides and ferrous hydroxides in the coal-mining 
waste crystallized in the form of hematite as they lost water. The presence of hematite in all likelihood reflects pyritic oxidation of the coal. Calcite, habitually found in the four coal cleaning residues, is easily differentiated from other calcium carbonates, due to its Raman spectrum, which showed bands of 1085, 711 and $280 \mathrm{~cm}^{-1}$ [30] in similar studies of a range of American coal samples. As observed in Brazilian materials, the Fe-oxide mineral hematite is commonly found in most coals and coal-cleaning residues.

XRD analysis between 600 and $900{ }^{\circ} \mathrm{C}$ showed reflections at $2.43 \AA\left(36.98^{\circ} 2 \theta\right)$ and $2.85 \AA$ $\left(31.38^{\circ} 2 \theta\right)$, revealing spinel-like phases, resulting from the heating of aluminous clay minerals. Hematite was present as a pyritic product in minor concentrations in the original coal waste and its presence increased at higher temperatures. At temperatures of 700,800 and $900{ }^{\circ} \mathrm{C}$, well crystallized hematite appeared following loss of water in the hydrous oxides and the ferrous hydroxides of the original coal waste. Finally, dolomite dissipated at $600{ }^{\circ} \mathrm{C}$ and subsequently, calcite at $700{ }^{\circ} \mathrm{C}$.

As oxidation continued, ferric sulfate was formed, eventually producing sodium, calcium, magnesium, and potassium sulfate.

The principal mineralogical compounds identified from the XRD data were subjected to FTIR analysis. Kaolinite was identified in the $(\mathrm{O}-\mathrm{H})$ bands at 3696,3656 and $3620 \mathrm{~cm}^{-1}$, mica at 3628 and $3545 \mathrm{~cm}^{-1}$ (both overlapping with kaolinite and water), and at $3423 \mathrm{~cm}^{-1}$. Standard carbonate group bands were detected at 1426 and $874 \mathrm{~cm}^{-1}$. With regard to silicates, Si-O vibrations revealed the presence of kaolinite at 1032 and $1007 \mathrm{~cm}^{-1}$ and quartz at $1090 \mathrm{~cm}^{-1}$ at tetrahedral sites. At lower frequencies ( $<1000 \mathrm{~cm}^{-1}$ ), the Al-O-H vibration, mainly associated with kaolinite (also at $751 \mathrm{~cm}^{-1}$ ) and mica, was detected at $912 \mathrm{~cm}^{-1}$. Vibrations of the Si-O quartz bond were identified at bands of 798,778 (doublet), 694, and $472 \mathrm{~cm}^{-1}$. OH absorption of mica is suggested by the presence of absorption bands in the $\mathrm{OH}$-stretching region at $3432 \mathrm{~cm}^{-1}$. The original coal residues revealed a further absorption band at $3656 \mathrm{~cm}^{-1}$, also explained by $\mathrm{OH}$ group stretching frequencies, which disappeared in the thermically activated waste. This observation points to the appearance of impure, low crystalline mica, and further isomorphous substitution in the crystalline structure.

Characterization of all tectosilicates, feldspars, and quartz was within the absorption band ranges of 950 to $1200 \mathrm{~cm}^{-1}$, reflecting stretching vibrations of $\mathrm{Si}-\mathrm{O}-\mathrm{Si}$, and between 400 and $550 \mathrm{~cm}^{-1}$, reflecting $\mathrm{O}-\mathrm{Si}-\mathrm{O}$ bending vibrations. Two hematite bands were observed at 535 and $469 \mathrm{~cm}^{-1}$, both overlapping the main band of mica. IR spectra $\left(465\right.$ and $\left.614 \mathrm{~cm}^{-1}\right)$ of the thermically activated waste revealed $\mathrm{AB}_{2} \mathrm{O}_{4}$ spinel.

A Raman spectrum in the thermically activated coal waste revealed two bands at 1597 and $1346 \mathrm{~cm}^{-1}$, corresponding to graphite and disordered peak bands, respectively, from carbon. The Raman spectrum of calcite, which is commonly found in all four coal-waste composites, may easily be differentiated from other calcium carbonates by its bands at 1085,711 and $280 \mathrm{~cm}^{-1}$.

\subsection{Pozzolanic Reactivity of Activated Coal-Mining Wastes}

The removal of structural water from the crystalline clay layers of calcined clay waste is a consequence of its pozzolanic reactivity, leaving semi-amorphous products with high surface areas and chemical reactivity. The calcining temperature that is required is dependent upon the nature of the clay mineral and the thermal energy required for dehydroxylation of the clays. The calcining temperature required to produce this active state is usually in the range $600-1000^{\circ} \mathrm{C}[9,12,38]$. Crystallization occurs above this temperature and activity declines. Even higher firing temperatures lead to the formation of a liquid phase that cools into a solid amorphous glass phase, also showing pozzolanic activity. Reactive metakaolinite is formed at $600{ }^{\circ} \mathrm{C}$ and hematite and spinel is formed between 600 and $900{ }^{\circ} \mathrm{C}$ that contains mica with a low crystallinity, at $900^{\circ} \mathrm{C}$; all of which contribute to the pozzolanic activity of the coal-mining wastes calcined to 600 and $900{ }^{\circ} \mathrm{C}$ (Figure 3). Clay minerals were shown to have pozzolanic activity that influenced the reaction kinetics. 


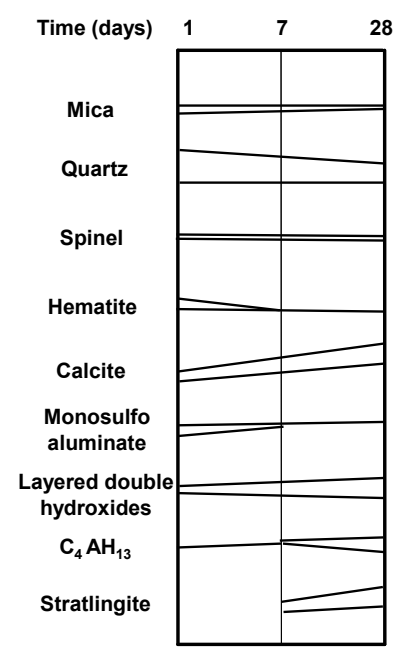

A

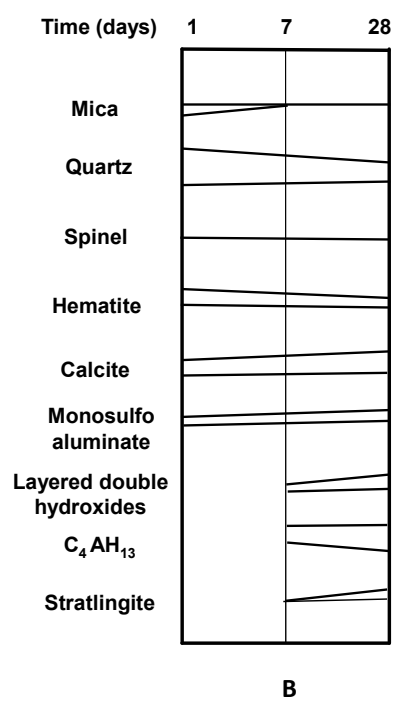

Figure 3. Mineralogical evolution of coal mining waste by XRD; (A) activated at $600{ }^{\circ} \mathrm{C} / 2 \mathrm{~h}$; (B) activated at $900^{\circ} \mathrm{C} / 2 \mathrm{~h}$.

The pozzolanic activity of the coal-mining waste that was activated at $600{ }^{\circ} \mathrm{C}$ and $900{ }^{\circ} \mathrm{C} / 2 \mathrm{~h} \mathrm{had}$ values, at one day, of $65.2 \%$, at $600{ }^{\circ} \mathrm{C}$, and $3.0 \%$, at $900{ }^{\circ} \mathrm{C}$; at seven days, these values were $67.2 \%$, at $600{ }^{\circ} \mathrm{C}$, and $33.1 \%$, at $900{ }^{\circ} \mathrm{C}$, and at 28 days into the reaction reached $72.4 \%$, at $600{ }^{\circ} \mathrm{C}$, and $65.8 \%$, at $900{ }^{\circ} \mathrm{C}$. These percentile results reflect a higher reaction rate at $600{ }^{\circ} \mathrm{C}$ than at $900{ }^{\circ} \mathrm{C}$, over short reaction times (one to seven days); both activated products showed a high pozzolanic activity in terms of the fixed lime results over longer reaction times (28 days).

Recommended activation conditions from both an energetic and an economic point of view were therefore set at $600{ }^{\circ} \mathrm{C} / 2 \mathrm{~h}$ retention time for the research.

\subsection{Evolution of Hydrated Phases in Activated Coal Waste/Lime Systems}

Characterization of the hydrated phases by XRD and SEM-EDX in both cases confirmed evidence of a pozzolanic reaction between the metakaolinate (from the coal waste) and the lime.

XRD analysis of the activated coal waste at $600{ }^{\circ} \mathrm{C}$ and $900{ }^{\circ} \mathrm{C}-2 \mathrm{~h} / \mathrm{Ca}(\mathrm{OH})_{2}$ at one, seven, and 28 days into the reaction revealed the following crystalline hydrated phases: stratlingite $\left(\mathrm{C}_{2} \mathrm{ASH}_{8}\right)$, tetracalcium aluminate hydrate $\left(\mathrm{C}_{4} \mathrm{AH}_{13}\right)$, monosulfoaluminate hydrate $\left(\mathrm{C}_{3} \mathrm{~A} \cdot \mathrm{SO}_{4} \mathrm{Ca} \cdot 12 \mathrm{H}_{2} \mathrm{O}\right)$, and layered double hydroxides. All the crystalline phases in the XRD analysis with their evolution and reaction times are shown in Figure 2. The formation of monosulfoaluminate hydrate $\left(\mathrm{C}_{3} \mathrm{~A} \cdot \mathrm{SO}_{4} \mathrm{Ca} \cdot 12 \mathrm{H}_{2} \mathrm{O}\right)$ in the thermically activated coal was evident at day one, as a consequence of the reaction between the reactive alumina of pozzolan, sulfate ions, and portlandite. Traces of tetracalcium aluminate hydrate $\left(\mathrm{C}_{4} \mathrm{AH}_{13}\right)$ were identified at short reaction times; slight increases in its content were observed in the coal waste activated at $600{ }^{\circ} \mathrm{C} / 2 \mathrm{~h}$ at day 28 of the reaction. Activation at $900{ }^{\circ} \mathrm{C}$ was joined by the formation of layer double hydroxides; stratlingite $\mathrm{C}_{2} \mathrm{ASH}_{8}$ was formed after seven days of reaction at $600{ }^{\circ} \mathrm{C} / 2 \mathrm{~h}$. Calcination at $900{ }^{\circ} \mathrm{C}$ prevented any further formation of stratlingite.

Alkaline solutions of these samples had $\mathrm{pH}$ values of $\approx 12$. The most prevalent were $\mathrm{Al}^{3+}$, $\mathrm{Al}(\mathrm{OH})_{2}{ }^{+}, \mathrm{Al}(\mathrm{OH})^{2+}, \mathrm{Al}(\mathrm{OH})_{3}$, and $\mathrm{Al}(\mathrm{OH})^{4-}$, without other ligands. The most prevalent species in the solution at high $\mathrm{pH}(\mathrm{pH}>10)$ was $\mathrm{Al}(\mathrm{OH})^{4-}$. These ions combined with readily available $\mathrm{Ca}^{2+}$ ions through metastable phases yielding $\mathrm{C}_{3} \mathrm{AH}_{6}$. At high $\mathrm{pH}$ values $(\mathrm{pH}>10)$, total dissolved silica concentrations in equilibrium with quartz and amorphous silica increased. At $\mathrm{pH}$ values of $\approx 12$, the sum of the ionized and un-ionized species $\left(\mathrm{H}_{4} \mathrm{SiO}_{4}, \mathrm{H}_{3} \mathrm{SiO}_{4}{ }^{-}\right.$, and $\left.\mathrm{H}_{2} \mathrm{SiO}_{4}{ }^{2-}\right)$ was equal to the total concentration of dissolved silica. If supersaturation of the total silica concentration in the solution with respect to amorphous silica occurs, polymers form that combine with the $\mathrm{Ca}^{2+}$ ions to form $\mathrm{CSH}$ 
(Calcium silicate hydrate) gels and with $\left(\mathrm{CO}_{3}\right)^{2-}$ ions via metastable phases to form LDH (Layered double hydroxides) [39].

The appearance of $\mathrm{C}_{4} \mathrm{AH}_{13}$ is explained by supersaturation of calcium hydroxide and low metakaolinite contents in the aqueous phase. Increased temperatures of coal waste at $900{ }^{\circ} \mathrm{C} / 2 \mathrm{~h}$ reduced the presence of alumina and metakaolinite and silica sheet structures, assisting the formation of the main hydration product, $\mathrm{C}_{4} \mathrm{AH}_{13}$.

Traces of portlandite and tetracalcium aluminate hydrate were identified at short reaction times $[40,41]$. However, tetracalcium aluminate hydrate was the prevalent phase in the pozzolanic reaction of coal waste at $900{ }^{\circ} \mathrm{C}$ at seven and 28 days; layered double hydroxides formed at day one of the reaction in coal waste at $600{ }^{\circ} \mathrm{C}$ to become the prevalent phase at day seven of the pozzolanic reaction. Stratlingite was evident at day seven of the reaction in the activated wastes and was the prevalent phase in the pozzolanic reaction after 28 days.

Following SEM analysis (Figure 4), an enriched composition of laminar microaggregates of silica were observed, with very porous surfaces covered with CSH gels, more abundantly at $600^{\circ} \mathrm{C} / 2 \mathrm{~h}$, having in all cases a spongy appearance. The $\mathrm{Ca} / \mathrm{Si}\left(\mathrm{CaO} / \mathrm{SiO}_{2}\right)$ ratio varied between 1.26 at $600{ }^{\circ} \mathrm{C}$ over $2 \mathrm{~h}$ (I-type gels) [10] and at all times was 1.73 in $900{ }^{\circ} \mathrm{C} / 2 \mathrm{~h}$ (II-type gels) [10]. A laminar phase, interlaced with the gels, consisted of layered double hydroxide, stratlingite $\mathrm{C}_{2} \mathrm{ASH}_{8}$, monosulfoaluminate hydrate $\left(\mathrm{C}_{3} \mathrm{~A} \cdot \mathrm{SO}_{4} \mathrm{Ca} \cdot 12 \mathrm{H}_{2} \mathrm{O}\right)$, and tetracalcium aluminate hydrate $\left(\mathrm{C}_{4} \mathrm{AH}_{13}\right)$ of widely varying sizes. SEM imagery showed a gradual layered double hydroxide with stratlingite crystallization throughout the hydrothermal treatment and an increase in crystal size that depended on the duration of the temperature. Both the SEM and the XRD analyses yielded similar results.
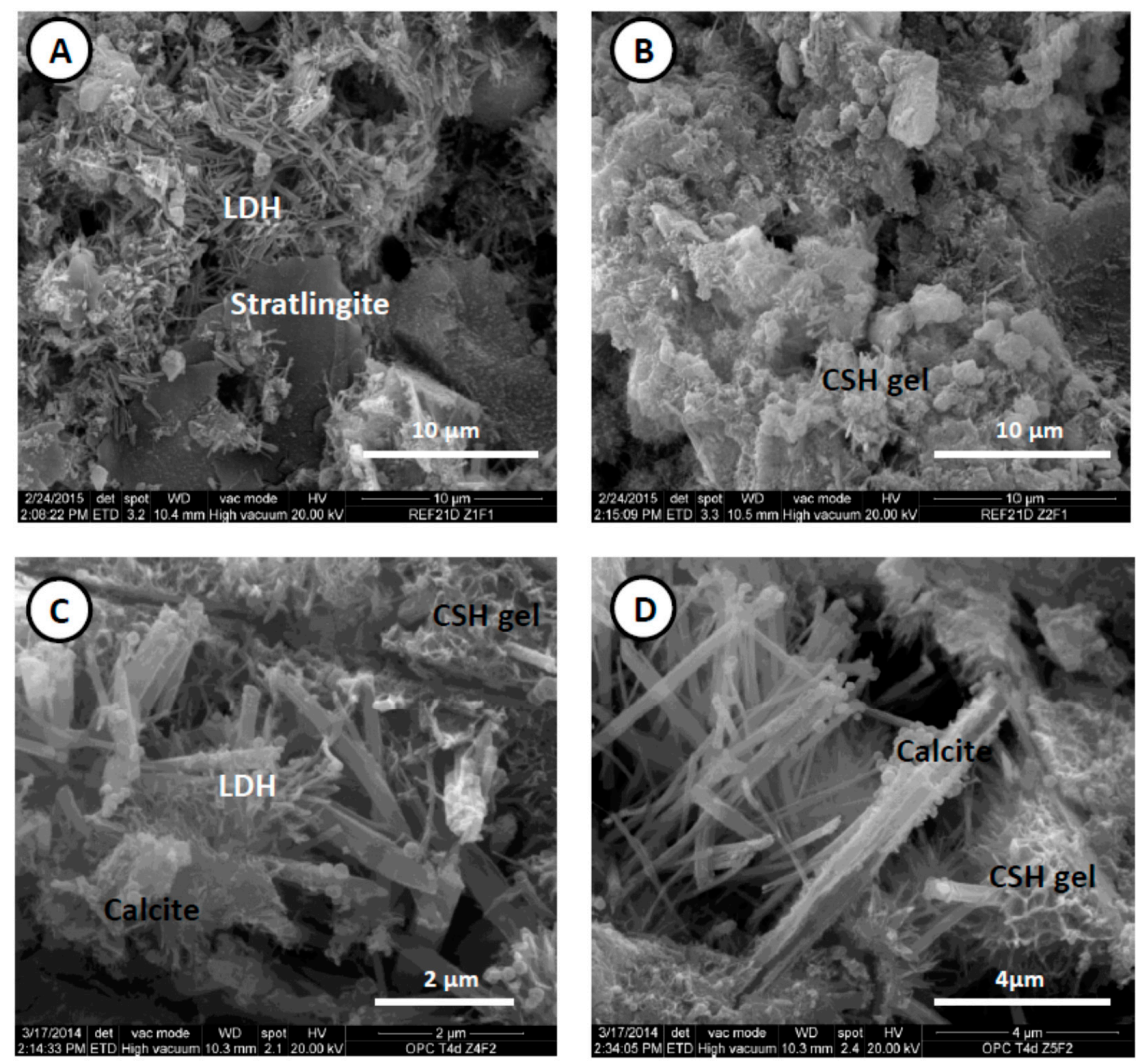

Figure 4. Morphological aspect of the CSH (Calcium silicate hydrate) gel, C4ASH12, and C2ASH8 phases at $600{ }^{\circ} \mathrm{C} / 2 \mathrm{~h}$ (A and B). Morphological aspect of the CSH gel, C4AH13 and LDH (Layered double hydroxide) structures at $900{ }^{\circ} \mathrm{C} / 2 \mathrm{~h}$ (C and D). (A) Layered double hydroxides with stratlingite; (B) Calcium silicate hydrate with spongy appearance; (C) Calcite crystal with typical morphology; (D) Calcite fibbers and layered double hydroxides. 


\section{Conclusions}

The coal waste that has been studied had a mineralogical composition of kaolinite, micas, quartz, calcite, dolomite, and feldspars.

The presence of kaolinite indicated that thermal treatment at $600{ }^{\circ} \mathrm{C} / 2 \mathrm{~h}$ transformed kaolinite in metakaolinite, a highly reactive component of the pozzolanic reaction.

Unlike hydrated phases obtained from a natural kaolinite $\left(\mathrm{CSH}\right.$ gels, $\mathrm{C}_{4} \mathrm{AH}_{13}$, and $\left.\mathrm{C}_{2} \mathrm{ASH}_{8}\right)$, metakaolinite from thermal activation of the coal-mining waste in the stable phase of the pozzolanic reaction assisted the appearance of metastable layered double hydroxide compounds and stratlingite. All these compounds indicate that the products resulting from thermal activation at $600{ }^{\circ} \mathrm{C} / 2 \mathrm{~h}$ from coal-mining waste contain highly pozzolanic properties over the first seven days into the reaction.

Following the activation of the coal-mining waste at $900{ }^{\circ} \mathrm{C} / 2 \mathrm{~h}, \mathrm{C}_{4} \mathrm{AH}_{13}$ was the stable phase in the pozzolanic reaction, following supersaturation of the aqueous phase in the presence of calcium hydroxide and low metakaolinite and tetrahedral and octahedral layers resulting from the dehydroxylation of the mica content. SEM/EDX analysis pointed to CSH gels among the main hydrated phases of the pozzolanic reaction in activated/lime systems during.

The use of this waste generates benefits and limits environmental damage such as (1) land occupation, and both soil and groundwater contamination, are reduced; (2) less exploitation of natural resources (kaolin deposits) and reduced emissions of greenhouse gases per unit of cement produced $\left(\mathrm{CO}_{2}\right.$ in the clinker production process); (3) coal waste containing residues of fossil carbon give the starting material a heating value which can be used in the alignment process (heating to the required temperature).

Acknowledgments: This research has been supported by the Spanish Ministry of Economy and Competitiveness (Project Ref. MAT2012-37005-CO3-01/02/03 and BIA2015-65558-C3-1-2-3R (MINECO/FEDER)). The authors are also grateful to the Sociedad Anónima Hullera Vasco-Leonesa and to the Spanish Cement Institute (IECA) for their assistance with this research.

Author Contributions: Moisés Frías and Raquel Vigil de la Villa Mencía conceived and designed the experiments; Virginia Rubio performed the experiments; Moisés Frías, Raquel Vigil de la Villa Mencía and Rosario García-Giménez analyzed the data; Virginia Rubio contributed materials and analysis tools; Rosario García-Giménez wrote the paper.

Conflicts of Interest: The authors declare no conflict of interest.

\section{References}

1. Zhao, Y.; Zhang, J.; Zheng, C.G. Transformation of aluminum-rich minerals during combustion of a bauxite-bearing Chinese coal. Int. J. Coal Geol. 2012, 94, 182-190. [CrossRef]

2. Liu, H.; Liu, Z. Recycling utilization patterns of coal mining waste in China. Res. Cons. Recycl. 2010, 54, 1331-1340.

3. Bian, Z.; Dong, J. The impact of disposal and treatment of coal mining wastes on environment and farmland. Environ. Geol. 2009, 58, 625-634. [CrossRef]

4. Skarzynska, K. Reuse of coal mining wastes in civil engineering-Part 2: Utilization of minestone. Waste Manag. 1995, 15, 83-126. [CrossRef]

5. Nehdi, M.; Duquette, J.; El Damatty, A. Performance of rice husk ash produced using a new technology as a mineral admixture in concrete. Cem. Concr. Res. 2003, 33, 1203-1210. [CrossRef]

6. Chindaprasirt, P.; Homwuttiwong, S.; Jaturapitakkul, C. Strength and water permeability of concrete containing palm oil fuel ash and rice husk-bark ash. Constr. Build. Mater. 2007, 21, 1492-1499. [CrossRef]

7. García Giménez, R.; Vigil de la Villa, R.; Goñi, S.; Frías, M. Fly ash/paper sludge as constituents of cements: Hydration phases. J. Environ. Eng. Sci. 2015, 10, 46-52. [CrossRef]

8. Frías, M.; Villar-Cociña, E.; Savastano, H. Brazilian sugar bagasse ashes from the cogeneration industry as active pozzolans for cement manufacture. Cem. Concr. Comp. 2011, 33, 490-496. [CrossRef]

9. Sabir, B.B.; Wild, S.; Bai, J. Metakaolin and calcined clays as pozzolans for concrete: A review. Cem. Concr. Comp. 2001, 23, 441-454. [CrossRef]

10. Taylor, H.F.W. Cement Chemistry, 1997; Thomas Telford Services Ltd.: London, UK, 1997. 
11. Siddique, R.; Klaus, J. Influence of metakaolin on the properties of mortar and Concrete: A review. Appl. Clay Sci. 2009, 43, 392-400. [CrossRef]

12. Ambroise, J.; Murat, M.; Pera, J. Hydration reaction and hardening of calcined clays and related minerals: V. Extension of the research and general conclusions. Cem. Concr. Res. 1985, 15, 261-268. [CrossRef]

13. De la Vigil Villa, R.; Frías, M.; Sánchez de Rojas, M.I.; Vegas, I.; García, R. Mineralogical and morphological changes of calcined paper sludge at different temperatures and retention in furnace. Appl. Clay Sci. 2007, 36, 279-286. [CrossRef]

14. Frias, M.; García, R.; Vigil, R.; Ferreiro, S. Calcination of art paper sludge waste for the use as a supplementary cementing material. Appl. Clay Sci. 2008, 42, 189-193. [CrossRef]

15. Banfill, P.F.G.; Rodríguez, O.; Sánchez de Rojas, M.I.; Frías, M. Effect of activation conditions of a kaolinite based waste on rheology of blended cement pastes. Cem. Concr. Res. 2009, 39, 843-848. [CrossRef]

16. Rodríguez Largo, O.; de la Vigil Villa, R.; de Sánchez Rojas, M.I.; Frías, M. Novel use of kaolin wastes in blended cements. J. Am. Ceram. Soc. 2009, 92, 2443-2446. [CrossRef]

17. Vegas, I.; Urreta, J.; Frías, M.; García, R. Freeze-thaw resistance of blended cements containing calcined paper sludge. Constr. Build. Mater. 2009, 23, 2862-2868. [CrossRef]

18. Frías, M.; Rodríguez, O.; Nebreda, B.; García, R.; Villar-Cocina, E. Influence of activation temperature of kaolinite based clay wastes on pozzolanic activity and kinetic parameters. Adv. Cem. Res. 2010, 22, 135-142. [CrossRef]

19. Li, D.; Song, X.; Gong, C.; Pan, Z. Research on cementitious behaviour and mechanism of pozzolanic cement with coal gangue. Cem. Concr. Res. 2006, 36, 1752-1759. [CrossRef]

20. Beltramini, L.B.; Suárez, M.L.; Guilarducci, A.; Carrasco, M.F.; Grether, R.O. Aprovechamiento de residuos de la depuración del carbón mineral: Obtención de adiciones puzolánicas para el cemento Portland. Revista Técnica de Ciencias. Universidad Tecnológica Nacional de Argentina 2010, 3, 7-18. (In Spanish)

21. Frías, M.; de Sánchez Rojas, M.I.; García, R.; Juan, A.; Medina, C. Effect of activated coal mining wastes on the properties of blended cement. Cem. Concr. Comp. 2012, 34, 678-683. [CrossRef]

22. Vigil de la Villa, R.; Frías, M.; García-Giménez, R.; Martínez-Ramírez, S.; Fernández-Carrasco, L. Chemical and mineral transformations that occur in mine waste and washery rejects during pre-utilization calcination. Int. J. Coal Geol. 2014, 132, 123-130. [CrossRef]

23. García, R.; Vigil de la Villa, R.; Frías, M.; Rodríguez, O.; Martínez-Ramírez, S.; Fernández-Carrasco, L.; de Soto, I.S.; Villar-Cociña, E. Mineralogical study of calcined coal waste in a pozzolan $/ \mathrm{Ca}(\mathrm{OH})_{2}$ system. Appl. Clay Sci. 2015, 108, 45-54. [CrossRef]

24. Leyva, F.; Matas, J.; Rodríguez Fernández, L.R. Memoria y Hoja del Mapa Geológico de España, Escala 1:50.000, No. 129 La Robla, $2^{a}$ Serie Magna; IGME: Madrid, Spain, 1984. (In Spanish)

25. Frías, M.; Vigil de la Villa, R.; García, R.; Sánchez de Rojas, M.I.; Baloa, T.A. Mineralogical evolution of kaolin-based drinking water treatment waste for use as pozzolanic material. The effect of activation temperature. J. Am. Ceram. Soc. 2012, 96, 3188-3195. [CrossRef]

26. Zimmer, A.; Bergmann, C.P. Fly ash of mineral coal as ceramic tiles raw material. Waste Manag. 2007, 27, 59-68. [CrossRef] [PubMed]

27. Dai, S.; Ren, D.; Chou, C.L.; Li, S.; Jiang, Y. Mineralogy and geochemistry of the No. 6 Coal (Pennsylvanian) in the Junger Coalfield, Ordos Basin, China. Int. J. Coal Geol. 2006, 66, 253-270. [CrossRef]

28. Vassilev, S.V.; Vassileva, C.G. Mineralogy of combustion wastes from coal-fired power stations. Fuel Process. Technol. 1996, 47, 261-280. [CrossRef]

29. Vassilev, S.V.; Vassileva, C.G. A new approach for the classification of coal fly ashes based on their origin, composition, properties, and behaviour. Fuel 2007, 86, 1490-1512. [CrossRef]

30. Ward, C.R.; Bocking, M.A.; Ruan, C. Mineralogical analysis of coals as an aid to seam correlation in the Gloucester Basin, New South Wales, Australia. Int. J. Coal Geol. 2001, 47, 31-49. [CrossRef]

31. Pinetown, K.L.; Ward, C.R.; van der Westhuizen, W.A. Quantitative evaluation of minerals in coal deposits in the Witbank and Highveld Coalfields, and the potential impact on acid mine drainage. Int. J. Coal Geol. 2007, 70, 166-183. [CrossRef]

32. Gaigher, J.L. The Mineral Matter in Some South African coals. Master Thesis, University of Pretoria, Pretoria, South Africa, 1980.

33. Ward, C.R. Analysis and significance of mineral matter in coal seams. Int. J. Coal Geol. 2002, 50, $135-168$. [CrossRef] 
34. Dai, S.; Tian, L.; Chou, C.L.; Zhou, Y.; Zhang, M.; Zhao, L.; Wang, J.; Yang, Z.; Cao, H.; Ren, D. Mineralogical and compositional characteristics of Late Permian coals from an area of high lung cancer rate in Xuan Wei, Yunnan, China: Occurrence and origin of quartz and chamosite. Int. J. Coal Geol. 2008, 76, 318-327. [CrossRef]

35. Ruan, C.-D.; Ward, C.R. Quantitative X-ray powder diffraction analysis of clay minerals in Australian coals using Rietveld methods. Appl. Clay Sci. 2002, 21, 227-240. [CrossRef]

36. Wang, X.; Dai, X.; Chou, C.; Zhang, M.; Wang, J.; Song, X.; Wang, W.; Jiang, Y.; Zhou, Y.; Ren, D. Mineralogy and geochemistry of Late Permian coals from the Taoshuping Mine, Yunnan Province, China: Evidences for the sources of minerals. Int. J. Coal Geol. 2012, 96, 49-59. [CrossRef]

37. Tian, L.; Dai, S.; Wang, J.; Huang, Y.; Ho, S.C.; Zhou, Y.; Lucas, D.; Koshland, C.P. Nanoquartz in Late Permian C1 coal and the high incidence of female lung cancer in the Pearl River Origin area: A retrospective cohort study. BMC Public Health 2008, 8, 398. [CrossRef] [PubMed]

38. Ambroise, J.; Martín Calle, S.; Pera, J. Pozzolanic behavior of thermally activated kaolin. In Proceedings of the Fourth CANMET / ACI International Conference on Fly Ash, SF, Slag and Natural Pozzolans in Concrete, Istambul, Turkey, 3-8 May 1992; Malhotra, V.M., Ed.; Volume 1, pp. 731-741.

39. De Wintd, L.; Deneele, D.; Maubec, N. Kinetic of lime/bentonite pozzolanic reaction at 20 and $50{ }^{\circ} \mathrm{C}$ : Batch tests and modeling. Cem. Concr. Res. 2014, 59, 34-42. [CrossRef]

40. Kaminskas, R.; Cesnauskas, V.; Kulibiute, R. Influence of different artificial additives on Portland cement hydration and hardening. Constr. Build. Mater. 2015, 95, 537-544. [CrossRef]

41. De Azeredo, A.F.N.; Azeredo, G.; Carneiro, A.M.P. Performance of lime-metakaolin pastes and mortars in two curing conditions containing kaolin wastes. Key Eng. Mater. 2016, 668, 419-432. [CrossRef]

(C) 2016 by the authors; licensee MDPI, Basel, Switzerland. This article is an open access article distributed under the terms and conditions of the Creative Commons Attribution (CC-BY) license (http://creativecommons.org/licenses/by/4.0/). 